\title{
RESEARCH
}

Open Access

\section{Human predecidual stromal cells are mesenchymal stromal/stem cells and have a therapeutic effect in an immune-based mouse model of recurrent spontaneous abortion}

Raquel Muñoz-Fernández ${ }^{1}$, Claudia De La Mata ${ }^{1}$, Francisco Requena², Francisco Martín ${ }^{3}$, Pablo Fernandez-Rubio ${ }^{1}$, Tatiana Llorca', Maria José Ruiz-Magaña ${ }^{1}$, Carmen Ruiz-Ruiz ${ }^{1,4+}$ and Enrique G. Olivares ${ }^{1,45^{*}+}$ (D)

\begin{abstract}
Background: Human decidual stromal cells (DSCs) are involved in the maintenance and development of pregnancy, in which they play a key role in the induction of immunological maternal-fetal tolerance. Precursors of DSCs (preDSCs) are located around the vessels, and based on their antigen phenotype, previous studies suggested a relationship between preDSCs and mesenchymal stromal/stem cells (MSCs). This work aimed to further elucidate the MSC characteristics of preDSCs.

Methods: We established 15 human preDSC lines and 3 preDSC clones. Physiological differentiation (decidualization) of these cell lines and clones was carried out by in vitro culture with progesterone (P4) and CAMP. Decidualization was confirmed by the change in cellular morphology and prolactin (PRL) secretion, which was determined by enzyme immunoassay of the culture supernatants. We also studied MSC characteristics: (1) In mesenchymal differentiation, under appropriate culture conditions, these preDSC lines and clones differentiated into adipocytes, osteoblasts, and chondrocytes, and differentiation was confirmed by cytochemical assays and RT-PCR. (2) The expression of stem cell markers was determined by RT-PCR. (3) Cloning efficiency was evaluated by limited dilution. (4) Immunoregulatory activity in vivo was estimated in DBA/2-mated CBA/J female mice, a murine model of immune-based recurrent abortion. (5) Survival of preDSC in immunocompetent mice was analyzed by RT-PCR and flow cytometry.
\end{abstract}

Results: Under the effect of P4 and CAMP, the preDSC lines and clones decidualized in vitro: the cells became rounder and secreted PRL, a marker of physiological decidualization. PreDSC lines and clones also exhibited MSC characteristics. They differentiated into adipocytes, osteoblasts, and chondrocytes, and preDSC lines expressed stem cell markers OCT4, NANOG, and ABCG2; exhibited a cloning efficiency of 4 to 15\%; significantly reduced the embryo resorption rate $(P<0.001)$ in the mouse model of abortion; and survived for prolonged periods in immunocompetent mice. The fact that 3 preDSC clones underwent both decidualization and mesenchymal differentiation shows that the same type of cell exhibited both DSC and MSC characteristics.

(Continued on next page)

\footnotetext{
*Correspondence: engarcia@ugr.es

${ }^{+}$Carmen Ruiz-Ruiz and Enrique G. Olivares jointly supervised this work.

${ }^{1}$ Instituto de Biopatología y Medicina Regenerativa, Centro de Investigación

Biomédica, Universidad de Granada, Granada, Spain

${ }^{4}$ Departamento de Bioquímica y Biología Molecular III e Inmunología,

Facultad de Medicina, Universidad de Granada, Avenida de la Investigación,

11, 18016 Granada, Spain

Full list of author information is available at the end of the article
}

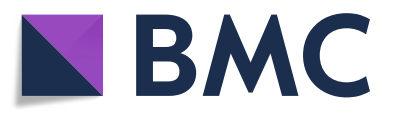

(c) The Author(s). 2019 Open Access This article is distributed under the terms of the Creative Commons Attribution 4.0 International License (http://creativecommons.org/licenses/by/4.0/), which permits unrestricted use, distribution, and reproduction in any medium, provided you give appropriate credit to the original author(s) and the source, provide a link to the Creative Commons license, and indicate if changes were made. The Creative Commons Public Domain Dedication waiver (http://creativecommons.org/publicdomain/zero/1.0/) applies to the data made available in this article, unless otherwise stated. 
(Continued from previous page)

Conclusions: Together, our results confirm that preDSCs are decidual MSCs and suggest that these cells are involved in the mechanisms of maternal-fetal immune tolerance.

Keywords: Clone cells, Decidua, Immune tolerance, Immunotherapy, Mesenchymal stromal cells, Predecidual stromal cells, Recurrent abortion

\section{Background}

Decidual stromal cells (DSCs), which constitute the main cellular component of human decidua, show activities that appear to play an important role in the embryo implantation [1], development of pregnancy [2], and maternalfetal immune tolerance [3-7]. These cells originate from perivascular fibroblastic precursors, which are detected in the gestational (decidua) as well as the nongestational endometrium $[8,9]$. Under the effect of ovarian hormones, these DSC precursors leave the vessels and differentiate into decidualized cells, which then spread throughout the stroma in the late luteal phase (decidualization). Decidualized cells change from a fibroblastic to a rounder shape and secrete prolactin (PRL) [10-12]. These differentiated cells are discarded during menstruation; however, if pregnancy takes place, the decidualization process continues because of the effect of pregnancy hormones $[8,9]$. Olivares et al. [13] introduced the term "predecidual stromal cells" (preDSCs) to designate the precursors of DSCs, and this term was later used by other authors [10, 14-16]. PreDSCs can be isolated from both the endometrium and decidua and cultured in vitro. Moreover, they decidualize, as in vivo, when incubated with progesterone (P4) and cAMP, changing to a rounder cell shape and secreting factors which are considered distinctive markers of decidualization, including PRL [13, 17].

The isolation and maintenance of highly purified human preDSC lines in culture allowed us to analyze the antigen phenotype of these cells and study their functions $[3-5,18,19]$. Based on the perivascular location of preDSCs, together with their expression of pericyte markers and angiogenic factors, their phagocytic activity, and their capacity to contract in vitro, we demonstrated a close relationship between preDSCs and pericytes [19], contractile cells that surround microvascular endothelial cells $[20,21]$. Furthermore, experimental evidence showed strong similarities between pericytes and mesenchymal stromal/stem cells (MSCs), and some have proposed that they constitute the same cell population [22-24]. In this connection, we previously confirmed that the antigen phenotype of preDSCs is compatible with MSCs $[5,19,25]$. Functions such as cell contractility, resistance to apoptosis, and inhibition of lymphocyte apoptosis are also shared by MSCs and preDSCs [18, 26-30]. Further evidence of a close relationship between preDSCs and MSCs was also reported by Dimitrov et al. [31].
Mesenchymal stromal/stem cells exhibit immunoregulatory activities in vivo and in vitro that show promise in the treatment of inflammatory and autoimmune diseases [32]. Therefore, to further elucidate the relationship between preDSCs and MSCs, the present study was designed to investigate the in vivo effects of preDSC lines in a murine model of immune system-mediated human recurrent spontaneous abortion. This is a well-known model in which CBA female mice are mated to DBA2 male mice, and pregnant $\mathrm{CBA} / 2$ animals have a high incidence of embryo resorption. Different immune cells and immunological mechanisms are involved in this resorption [33, 34]. We considered this murine model appropriate to investigate both the potential regulatory effect of preDSCs in immune-based human recurrent abortion and the role of preDSCs in maintaining maternal-fetal immune tolerance.

\section{Materials and methods Samples}

For the preDSC lines, samples from elective vaginal terminations of first-trimester pregnancies (6-11 weeks) were collected from 15 healthy women aged $20-30$ years. We excluded women who were using any medication or with infectious, autoimmune, or other systemic or local disease. None of the abortions was pharmacologically induced. The specimens were obtained by suction curettage at the Clínica El Sur in Málaga or the Clínica Ginegranada in Granada. For the 3 human foreskin fibroblast (HFF) lines, foreskin samples were obtained from patients at the Hospital Universitario San Cecilio in Granada.

\section{Isolation and culture of preDSC and HFF lines}

We used the preDSC lines obtained in recent work as reported earlier [19]. These lines consisted of a highly purified, uniform, adherent cell population in which almost all cells expressed the endometrial stromal cell marker CD10 [35], together with CD13, CD29, CD44, CD73, CD90, CD105, $\alpha$-smooth muscle (SM) actin, nestin, podoplanin, and vimentin, and lacked CD15, CD19, CD34, CD45, CD62P, and HLA-DR expression. This antigen phenotype is fully compatible with that of bone marrow MSCs [19, 36] (Table 1). To establish HFF lines from the human foreskin, we used the method described by Kimatrai and colleagues [28] to establish preDSC lines from the decidua. Briefly, foreskin samples were minced between two 
Table 1 Antigen expression by preDSC and bone marrow MSC lines obtained in the same conditions $[19,36]$

\begin{tabular}{|c|c|c|}
\hline \multirow[t]{2}{*}{ Antigen } & \multicolumn{2}{|c|}{ Flow cytometry reactions } \\
\hline & preDSCs & MSCs \\
\hline$\overline{C D 10^{a}}$ & + & + \\
\hline $\mathrm{CD} 13^{\mathrm{a}}$ & + & + \\
\hline CD15 & - & - \\
\hline $\mathrm{CD} 19^{\mathrm{b}}$ & - & - \\
\hline $\mathrm{CD} 29^{\mathrm{a}}$ & + & + \\
\hline CD31 & - & - \\
\hline $\mathrm{CD} 34^{\mathrm{b}}$ & - & - \\
\hline $\mathrm{CD} 44^{\mathrm{a}}$ & + & + \\
\hline $\mathrm{CD} 45^{\mathrm{b}}$ & - & - \\
\hline CD54 & + & + \\
\hline CD62P & - & - \\
\hline $\mathrm{CD} 3^{\mathrm{a}, \mathrm{b}}$ & + & + \\
\hline$C D 90^{a, b}$ & + & + \\
\hline CD105 & + & + \\
\hline CD106 & $+/-^{c}$ & $+/-^{c}$ \\
\hline CD140b & + & ND \\
\hline CD146 & + & + \\
\hline CD271 & + & + \\
\hline AP & + & ND \\
\hline a-SM actin & + & + \\
\hline HLA-G & + & $+/-$ \\
\hline$H L A-D R^{b}$ & - & - \\
\hline MFGE8 & + & ND \\
\hline Nestin $^{a}$ & + & + \\
\hline ОСТз/4 & + & + \\
\hline Podoplanin ${ }^{a}$ & + & + \\
\hline STRO-1 & + & + \\
\hline Vimentin ${ }^{a}$ & + & ND \\
\hline W5C5 & + & + \\
\hline
\end{tabular}

ND not done

${ }^{\text {a }}$ Antigens expressed by more than $95 \%$ of cells

${ }^{b}$ Antigens meeting the minimal criteria for identification as MSC [37]

'Some lines expressed the antigen and some did not

scalpels in a small volume of PBS. The suspension was mixed with a solution of $5 \mathrm{mg} / \mathrm{mL}$ collagenase $\mathrm{V}$ (Sigma-Aldrich, St. Louis, MO, USA) for $30 \mathrm{~min}$ at $37^{\circ} \mathrm{C}$. The suspension was diluted in PBS and centrifuged at $425 \mathrm{~g}$ for $10 \mathrm{~min}$. The cell pellet was suspended in PBS and centrifuged on Ficoll-Paque (Sigma-Aldrich) for $20 \mathrm{~min}$ at $600 \mathrm{~g}$. Foreskin cells were collected from the interface, suspended in PBS, and washed. The resulting suspension was incubated in culture flasks for $24 \mathrm{~h}$ at $37^{\circ} \mathrm{C}$ with $5 \% \mathrm{CO}_{2}$ in Opti-MEM (minimum essential medium) (Invitrogen, Grand Island, NY, USA) supplemented with $3 \%$ fetal calf serum (FCS) (Invitrogen), $100 \mathrm{IU} / \mathrm{mL}$ penicillin, $100 \mu \mathrm{g} / \mathrm{mL}$ streptomycin, and $0.25 \mu \mathrm{g} / \mathrm{mL}$ amphotericin (Sigma-Aldrich). After overnight incubation to allow adherent cells to attach to the flask, nonadherent cells in the supernatant were discarded. The medium was then replaced and changed thereafter twice a week. After 1-3 weeks, adherent cells were morphologically uniform and covered the whole surface of the $25-\mathrm{cm}^{2}$ culture flask. Cells were split with a trypsinEDTA solution of $0.25 \%$ (Sigma-Aldrich) when they were 90 to $100 \%$ confluent. Although the different cell lines are referred to generically as preDSCs or HFFs, in experiments with several lines of the same type of cell, we used a specific designation for each line (e.g., preDSC1, preDSC2). For this study, 15 preDSC and 3 HFF lines were obtained (each from a different sample) and were always used between 3 and 8 weeks after collection (up to 5 passages). The maternal origin of each preDSC line was confirmed by comparison with its corresponding trophoblast obtained from the same sample, using short tandem repeat markers and quantitative-fluorescent PCR (Devyser AB, Hägersten, Sweden).

\section{Cell cloning}

We used three preDSC clones obtained in earlier work [19]. Predecidual stromal cell clones were obtained from preDSC lines by limiting dilution in 96-well plates, using complete Opti-MEM supplemented with 10\% FCS. Three days after cell seeding, the plates were checked and wells with only one cell were selected. After 2 weeks, single cells had formed colonies which we then trypsinized and seeded into 24-well plates for culture in complete Opti-MEM supplemented with 3\% FCS.

\section{Decidualization}

To induce decidualization, preDSC lines or clones were treated with $300 \mathrm{nM} \mathrm{P} 4$ and $500 \mu \mathrm{M}$ dibutyryl cAMP (Sigma-Aldrich) for 15 days. Decidualization was verified by PRL secretion and changes in cell morphology from a fibroblastic to a round shape, as observed with light microscopy. The presence of PRL was verified with an electrochemiluminescence immunoassay (Roche, Indianapolis, IN, USA). The assays were performed according to the manufacturer's instructions, and all samples were tested in duplicate.

\section{Mesenchymal differentiation}

For osteogenic differentiation, preDSCs were plated on a fresh tissue culture dish at 80 to $90 \%$ confluency in Opti-MEM. The cells were allowed to attach for a minimum of $24 \mathrm{~h}$ and rinsed with PBS. Complete osteogenic differentiation medium (Opti-MEM supplemented with $10 \mathrm{nM}$ ascorbic acid, $10 \mathrm{nM} \beta$-glycerol phosphate, 100 $\mathrm{nM}$ dexamethasone [Sigma-Aldrich], and 3\% FCS) was added, and the cells were incubated at $37^{\circ} \mathrm{C}$ with $5 \%$ 
$\mathrm{CO}_{2}$ with humidity. Every 3 days, the medium was replaced with fresh complete osteogenic differentiation medium. Osteogenesis required approximately 21-28 days and was verified by the formation of tightly packed, elongated osteoblasts. In addition, the mineralized matrix was detected by alizarin staining (Sigma-Aldrich). For adipogenic differentiation, cells were plated on 5\% FCSOpti-MEM in culture dishes and incubated at $37^{\circ} \mathrm{C}$ in $5 \%$ $\mathrm{CO}_{2}$. Two days after confluency, the cells were stimulated with induction medium consisting of $100 \mu \mathrm{M}$ 3-isobutyl1 -methylxanthine, $1 \mu \mathrm{M}$ dexamethasone, $100 \mu \mathrm{M}$ indomethacin (Sigma-Aldrich), and $10 \mu \mathrm{g} / \mathrm{mL}$ insulin (Novo Nordisk, Bagsvaerd, Denmark). Full differentiation was usually achieved by day 15 . Lipid droplets were visualized with oil red O solution (Sigma-Aldrich). For chondrogenic differentiation, adherent cell colonies were trypsinized and counted, and the medium was replaced with serum-free Opti-MEM supplemented with $10 \mathrm{ng} / \mathrm{mL}$ TGF- $\beta 1$ (SigmaAldrich). Aliquots of $2 \times 10^{5}$ cells in $1 \mathrm{~mL}$ medium were then centrifuged in conical polypropylene tubes. The pelleted cells were incubated at $37^{\circ} \mathrm{C}$ in $5 \% \mathrm{CO}_{2}$. Within $24 \mathrm{~h}$ after incubation, the cells formed an aggregate that did not adhere to the walls of the tube. The medium was changed every 2 or 3 days, and the cell aggregates were obtained at intervals of up to 21 days. To detect proteoglycans, 4- $\mu \mathrm{m}$-thick frozen sections of aggregates were stained with safranin O solution (Sigma-Aldrich).

\section{Colony-forming unit test}

Briefly, preDSCs were plated $\left(100\right.$ cells $\left./ \mathrm{cm}^{2}\right)$ in 6-well plates with $2 \mathrm{~mL}$ Opti-MEM supplemented with $3 \%$ FCS, $100 \mathrm{IU} / \mathrm{mL}$ penicillin, $100 \mu \mathrm{g} / \mathrm{mL}$ streptomycin, and $0.25 \mu \mathrm{g} / \mathrm{mL}$ amphotericin. The plates were incubated at $37^{\circ} \mathrm{C}$ with $5 \% \mathrm{CO}_{2}$ for 15 days. Colonies were monitored daily with light microscopy to verify they were derived from single cells. The colonies were stained with $0.1 \%$ crystal violet (Sigma-Aldrich) for $5 \mathrm{~min}$ at room temperature and washed with distilled water. Only colonies with more than 50 cells were counted. The percent cloning efficiency $(\mathrm{CE})$ was calculated with the following formula: $\mathrm{CE}(\%)=$ number of colonies/number of cells seeded.

\section{Reverse transcription polymerase chain reaction}

The primers used in this study, all from the Instituto de Parasitología y Biomedicina, Granada, Spain, are detailed in Table 2. Octamer-binding transcription factor 4 (OCT-4) primers were obtained from Integrated DNA Technologies (Leuven, Belgium). To distinguish bona fide OCT-4 transcripts from pseudogene transcripts, we performed RT-PCR assays with two different forward primers and one intron-spanning reverse primer (Oct4R). One of the forward primers (Oct4FP) recognizes an exclusive polymorphism of OCT-4, which makes it possible to
Table 2 Primer sequences used for RT-PCR

\begin{tabular}{|c|c|c|}
\hline mRNA & Oligonucleotide primers & $\begin{array}{l}\text { PCR product } \\
\text { size (bp) }\end{array}$ \\
\hline $\begin{array}{l}\text { ATP-binding cassette } \\
\text { subfamily G member } \\
2 \text { (ABCG2) }\end{array}$ & $\begin{array}{l}\text { 5'-CCCATCCTGACCTCCAGCCG-3' (F) } \\
5^{\prime}-\text { TTGAGTGGGCACAGCACGCA-3' (R) }\end{array}$ & 127 \\
\hline $\begin{array}{l}\text { Alkaline phosphatase } \\
\text { (AP) }\end{array}$ & $\begin{array}{l}\text { 5'-TGGAGCTTCAGAAGCTCAACACCA-3' (F) } \\
\text { 5'-ATCTCGTTGTCTGAGTACCAGTCC-3' (R) }\end{array}$ & 338 \\
\hline$\beta 2$-microglobulin & $\begin{array}{l}\text { 5'-CTCGCGCTACTCTCTCTCTITCTGG-3' (F) } \\
\text { 5'-TCTACATGTCTCGATCCCACTTAA-3' (R) }\end{array}$ & 335 \\
\hline Collagen II & $\begin{array}{l}\text { 5'-TTTCCCAGGTCAAGATGGTC-3' (F) } \\
5^{\prime} \text {-CTTCAGCACCTGTCTCACCA-3' (R) }\end{array}$ & 159 \\
\hline $\begin{array}{l}\text { Human cytochrome } \\
\text { B (Cyt B) }\end{array}$ & $\begin{array}{l}\text { 5'-CCCATACATTGGGACAGACC-3' (F) } \\
\text { 5'-GACGGATCGGAGATTGTGT-3' (R) }\end{array}$ & 394 \\
\hline Murine Cyt B & $\begin{array}{l}\text { 5'-TCGCGGCCCTAGCAATCGTT-3' (F) } \\
\text { 5'-TGGTTGGCCCCCAATTCAGGT-3'(R) }\end{array}$ & 461 \\
\hline NANOG & $\begin{array}{l}\text { 5'-TGCTGGACTGAGCTGGTTGCC-3' (F) } \\
\text { 5'-AGCAAGGCAAGCTITGGGGACA-3' (R) }\end{array}$ & 221 \\
\hline $\begin{array}{l}\text { Octamer-binding } \\
\text { transcription factor } \\
4 \text { (OCT-4) }\end{array}$ & $\begin{array}{l}\text { Oct4F: 5'-AGCCCTCATTTCACCAGG } \\
\text { CC-3'(F) } \\
\text { Oct4FP: 5'-GATGGCGTACTGTGGGCC } \\
\text { C-3' (F) } \\
\text { Oct4R: 5'-TGGGACTCCTCCGGGTाT } \\
\text { TG-3' (R) }\end{array}$ & $\begin{array}{l}456 \\
195\end{array}$ \\
\hline Osteopontin & $\begin{array}{l}\text { 5'-CTAGGCATCACCTGTGCCATACC--3' (F) } \\
5^{\prime} \text {-CAGTGACCAGTTATCAGATCATC-3' (R) }\end{array}$ & 373 \\
\hline $\begin{array}{l}\text { Peroxisome proliferator- } \\
\text { activated receptor }{ }^{2} \\
\text { (PPARy2) }\end{array}$ & $\begin{array}{l}\text { 5'-GCTGTTATGGGTGAAACTCTG-3' (F) } \\
\text { 5'-ATAAGGTGGAGATGCAGGCTC-3' (R) }\end{array}$ & 351 \\
\hline
\end{tabular}

distinguish its corresponding transcript from pseudogene transcripts. The other forward primer (Oct4F) recognizes a nonhomologous region of pseudogenes [38].

Total RNA was extracted from cells with the TRIzol isolation method, and cDNA was synthesized with Oligo-dT primers and Moloney murine leukemia virus $\mathrm{H}$ minus ribonuclease reverse transcriptase (Invitrogen) according to the manufacturer's protocol. For RT-PCR, we used a 2720 Thermal Cycler (Applied Biosystems, Darmstadt, Germany). The reaction mixture (total volume $20 \mu \mathrm{L}$ ) contained cDNA (equivalent of $100 \mathrm{ng}$ RNA), $200 \mathrm{nM}$ deoxy-NTPs (Biotools, Madrid, Spain), $800 \mathrm{~nm}$ of each primer, and $0.5 \mathrm{U}$ GoTaq polymerase (Biotools). After incubation for $3 \mathrm{~min}$ at $95^{\circ} \mathrm{C}$, each cycle consisted of $95^{\circ} \mathrm{C}$ for $30 \mathrm{~s}, 55^{\circ} \mathrm{C}$ for $45 \mathrm{~s}$, and $72{ }^{\circ} \mathrm{C}$ for $45 \mathrm{~s}$, for a total of 35 cycles. The RT-PCR products were sizeseparated on ethidium bromide-stained $2 \%$ agarose gels (PanReact AppliChem, Barcelona, Spain), and a 100-bp DNA ladder was included in each run.

\section{Plasmids, lentiviral constructs, vector production, titration, and preDSC transduction}

The HIV packaging (pCMVAR8.91) and the vesicular stomatitis virus G glycoprotein (VSVg) (pMD.G) plasmids were kindly provided by D. Trono (University of Geneva, Geneva, Switzerland). The packaging plasmid 
pCMVAR8.91 encodes gag, pol, tat, and rev genes. The pMD.G plasmid encodes $V S V g$. The CEWP lentiviral vectors express an enhanced green fluorescent protein (GFP) through the cytomegalovirus (CMV) promoter [39]. Lentiviral vectors were produced by cotransfection of 293T kidney cells (human embryonic kidney cells, CRL-11268, ATCC) as previously described [40]. Briefly, the three plasmids encoding the vector genome (CEWP), the gag-pol-tat-rev proteins (packaging plasmid- pCMV $\Delta$ R8.91), and the envelope glycoprotein (pMD.G) were transfected into $293 \mathrm{~T}$ cells with Lipofectamine 2000 (Invitrogen). Viral supernatants were collected and filtered through a $0.45-\mu \mathrm{m}$ filter. Vector particles were concentrated by ultrafiltration at $2000 \times g, 4{ }^{\circ} \mathrm{C}$ with 100 $\mathrm{kDa}$ centrifuge filter devices as previously described [41] (Amicon Ultra-15, Millipore, Billerica, MA, USA). Vector supernatants were immediately frozen at $-80^{\circ} \mathrm{C}$ or used to transduce preDSCs. Briefly, preDCSs were detached from the culture flask, washed with PBS, resuspended in vector supernatant at a multiplicity of infection of 10 , and left in the incubator for 5-6 h. The viral supernatant was removed and replaced with fresh Opti-MEM culture medium. Four to 6 days later, the CEWP-transduced preDSCs were analyzed by FACS for GFP expression. The antigen phenotype, cell viability, and proliferation of transduced preDSCs were equivalent to those of nontransduced preDSCs.

\section{Mice}

Eight- to 10-week-old BALB/c, DBA/2, and CBA/J mice (Janvier Labs, Le Genest-Saint-Isle, France) were housed in our center's animal facility (Centro de Investigación Biomédica, Universidad de Granada) in stable humidity and temperature conditions on a 12:12-h light/dark cycle, with free access to food and water. All necessary steps were taken to ensure maximum comfort of the animals and compliance with current regulations on the maintenance and use of experimental animals.

\section{Murine model of recurrent abortion}

Virgin female CBA mice were mated to male BALB/C mice (control mating combination) or DBA2 male mice (abortion-prone mating combination). For each combination, we established three groups: control PBS (intraperitoneal injection of $0.5 \mathrm{~mL}$ PBS), control HFFs (intraperitoneal injection of $10^{6}$ HFFs in $0.5 \mathrm{~mL}$ PBS), and preDSC (intraperitoneal injection of $10^{6}$ preDSCs in $0.5 \mathrm{~mL}$ PBS). HFFs were used in these experiments as a negative control for preDSCs, because both types of cell are fibroblastic cells. Pregnancy was verified by the presence of a vaginal plug (gestation day 0.5), and 1.5 days later, we injected PBS or preDSCs. The animals were killed on day 14 of gestation, and the number of embryo implants and embryo resorptions was recorded in each pregnant mouse. The results were expressed as resorption rate: the percentage of reabsorbed embryos (no embryo in the implantation site) referred to the total number of implanted embryos.

\section{Detection of human preDSCs in the mice tissues}

The presence of preDSCs after intraperitoneal injection in pregnant $\mathrm{CBA} / \mathrm{J}$ mice in the murine model of recurrent abortion was determined by RT-PCR with human $\mathrm{B}$ cytochrome (Cyt B) primers for human mitochondrial DNA. Pellets $(0.5 \mathrm{~mL})$ of centrifuged blood or small pieces of dispersed spleen tissue were suspended in $0.5 \mathrm{~mL}$ of a solution of $0.1 \mathrm{M}$ EDTA and $50 \mathrm{Mm}$ TRIS $(\mathrm{pH}=8)$ containing $0.5 \%$ SDS and $1 \mathrm{mg} / \mathrm{mL}$ proteinase $\mathrm{K}$ (Roche, Roche Diagnostics, Basel, Switzerland) and incubated overnight at $55^{\circ} \mathrm{C}$. Fifty microliters of a 3-M sodium acetate solution $(\mathrm{pH} 7)$ and then $0.5 \mathrm{~mL}$ of a phenolchloroform (1:1) solution were added. The samples were vortexed and centrifuged at 16,200 $g$ for $5 \mathrm{~min}$ at room temperature. Four hundred microliters of the upper aqueous phase was collected and mixed with $350 \mu \mathrm{L}$ isopropanol, and the mixture was centrifuged at $16,200 \mathrm{~g}$ for $5 \mathrm{~min}$ at room temperature. The supernatant was discarded, and the pellet was washed with absolute ethanol at $16,200 g$ for $5 \mathrm{~min}$ at room temperature. The supernatant was again discarded, and the pellet was suspended in milliQ water and incubated overnight at $55^{\circ} \mathrm{C}$. Polymerase chain reaction was done with a 2720 thermal cycler (Applied Biosystems). The PCR mixture contained 800 ng DNA, $200 \mu \mathrm{M}$ dNTPs, and $10 \mu \mathrm{M}$ of each primer in a total volume of $50 \mu \mathrm{L}$. The PCR reactions were run with an initial step at $95^{\circ} \mathrm{C}$ for $10 \mathrm{~min}$ followed by 35 cycles at $94^{\circ} \mathrm{C}$ for $1 \mathrm{~min}$, $60^{\circ} \mathrm{C}$ for $1 \mathrm{~min}$, and $72^{\circ} \mathrm{C}$ for $1 \mathrm{~min}$.

We also injected $10^{6}$ CEWP-transduced preDSCs suspended in PBS intraperitoneally in virgin female BALB/c mice. The animals were killed on different days, and the blood, spleen, and inguinal lymph nodes were collected. Blood was diluted in PBS and centrifuged on FicollPaque (Sigma-Aldrich). Lymph node and spleen tissues were disaggregated with $5 \mathrm{mg} / \mathrm{mL}$ collagenase V (SigmaAldrich) for $30 \mathrm{~min}$ at $37^{\circ} \mathrm{C}$, washed, suspended in PBS, and centrifuged on Ficoll-Paque (Sigma-Aldrich). Cells were collected from the interface, suspended in PBS, and analyzed in a FACScan cytometer (BD Biosciences, San Diego, CA, USA). Tissues from BALB/c mice in which nontransduced preDSCs had been injected were used as the negative control for flow cytometry.

\section{Statistical analysis}

The figures illustrate the results for a single experiment representative of three or more separate assays. All experiments were done in triplicate or quadruplicate. The Wilcoxon test was used to compare the results for the changes in morphology and PRL secretion. To study recurrent abortion, the results were analyzed with the chi-squared 
test corrected for a cluster sampling design (Rao-Scott correction) [42], as uncorrected chi-squared or Fisher's exact tests, used by other authors, may yield misleading results. Values of $P<0.05$ were considered significant.

\section{Results}

\section{MSC characteristics of preDSC lines}

The preDSC lines were composed of a highly purified uniform population of proliferating fibroblast-shaped adherent cells [19]. These cells exhibited an antigen phenotype compatible with that of MSCs $[19,36]$ (Table 1). In cultures with cAMP and $\mathrm{P} 4$, preDSC lines decidualized, changing their morphology from a fibroblastic to a rounder shape and secreting PRL (Fig. 1a). Furthermore, by RT-PCR, we detected the pluripotent stem cell markers OCT-4, NANOG, and ABCG2 in preDSCs (Fig. 1b) - markers also associated with MSCs [43]. Detecting OCT-4 transcripts by RT-PCR is always a challenge, since artifacts are easily induced by the amplification of many OCT-4-like transcripts originating from the expression of processed and nonprocessed pseudogenes. Both forward primers, i.e., OCT-4-specific OCT4FP and OCT-4F, which also amplifies pseudogenes, were positive in all 4 preDSC lines. The colony-forming efficiency of the preDSC lines ranged between 4 and 15\% (Fig. 1c). Under appropriate culture conditions, preDSCs differentiated into the three different mesenchymal lineages-adipocytes, osteoblasts, and chondrocytes-as confirmed by cytochemical assays and RT-PCR (Fig. 1d).

\section{PreDSC clones exhibited both DSC and MSC characteristics}

Three preDSC clones showed an antigen phenotype equivalent to that expressed by preDSC lines, and also compatible with that of bone marrow MSC $[19,36]$. When these three clones were cultured with $\mathrm{P} 4$ and cAMP, they also changed their cell morphology toward a rounder shape and secreted PRL. Under appropriate conditions, these three clones also differentiated into adipocytes, chondrocytes, and osteoblasts (Fig. 2). These results demonstrated that the same type of cell can undergo decidual or mesenchymal differentiation.

\section{PreDSC lines reduced the resorption/implantation ratio in the abortive mating combination female $\mathrm{CBA} / \mathrm{J} \times$ male $\mathrm{DBA} / 2$}

To study the in vivo immunoregulatory activity of preDSCs, we injected these cells in the abortion-prone mating combination $\mathrm{CBA} / \mathrm{J}+\mathrm{P} \times \mathrm{DBA} / 2 \hat{\jmath}$. As expected, in this combination, the resorption/implantation ratio was significantly higher than in the nonabortion-prone mating combination $\mathrm{CBA} / \mathrm{J}+\mathrm{BALB} / \mathrm{c} \widehat{O}(P<0.01)$. The injection of preDSCs in the abortion-prone mating combination led to a significant reduction in the resorption/implantation ratio $(P<0.001)$, whereas control HFFs increased this ratio, although not significantly. The injection of preDSCs and HFFs in the control mating combination had no significant effect (Fig. 3a, Additional file 1: Table S1).

\section{Detection of human preDSCs injected in immunocompetent mice}

The results with RT-PCR for the human marker Cyt B confirmed the presence of preDSCs on day 14 of gestation, i.e., 12 days after the injection of human preDSCs in both control and experimental animals in the murine model of recurrent abortion. These cells were detected in the blood, in the spleen from BALB/c-mated pregnant $\mathrm{CBA} / \mathrm{J}$ mice, and in the spleen of $\mathrm{DBA} / 2$-mated pregnant CBA/J mice (Table 3). Blood and spleen samples from CBA/J mice in which preDSCs were not injected were all negative for human Cyt B, but all samples were positive for murine Cyt B (Fig. 3b). Although human Cyt $\mathrm{B}$ might have been detected in murine macrophages that could have phagocytosed preDSCs, it is highly unlikely that preDSC mitochondrial DNA would survive in macrophages for up to 12 days after human preDSCs were injected.

We also confirmed the presence of live preDSCs in virgin female $\mathrm{BALB} / \mathrm{c}$ mice by injecting GFP-labeled preDSCs. These cells were detected by flow cytometry in the blood after 2 days and in the inguinal lymph nodes after 45 days. Thirty days after the injection, preDSCs appeared to be present in the spleen. PreDSCs were not found in the blood after 45 days, in the inguinal lymph nodes after 2 days, or in the spleen after 2 days (Fig. 4, Table 3). Because the degradation half-life of GFP is only a few hours [44], the detection of this protein in cells days and weeks after the injection in the mice indicates active GFP synthesis by preDSCs that remain alive.

The aim of these experiments was not to establish a precise dynamic of the diffusion of preDSCs in different tissues and organs but to confirm the ability of these cells to survive in the short, middle, and long term in immunocompetent mice. In general, our results showed that preDSCs survived in the blood in the short term (2 days) and in the middle term (12 days) in $100 \%$ of mice, but these cells disappeared from this tissue in the long term (45 days). In the lymph nodes and spleen, preDSCs were not detected in the short term; however, these cells were found in the middle (in 2 of out 6 mice) and long term ( 1 of out 3 mice) in spleen tissue. In all, preDSCs survived in 10 of out 27 mice (Table 3 ).

\section{Discussion}

Our preDSC lines consisted of a highly purified, uniform, adherent cell population. Under the effects of cAMP and P4, these cells displayed the physiological differentiation pathway (decidualization) of DSCs: their 
A
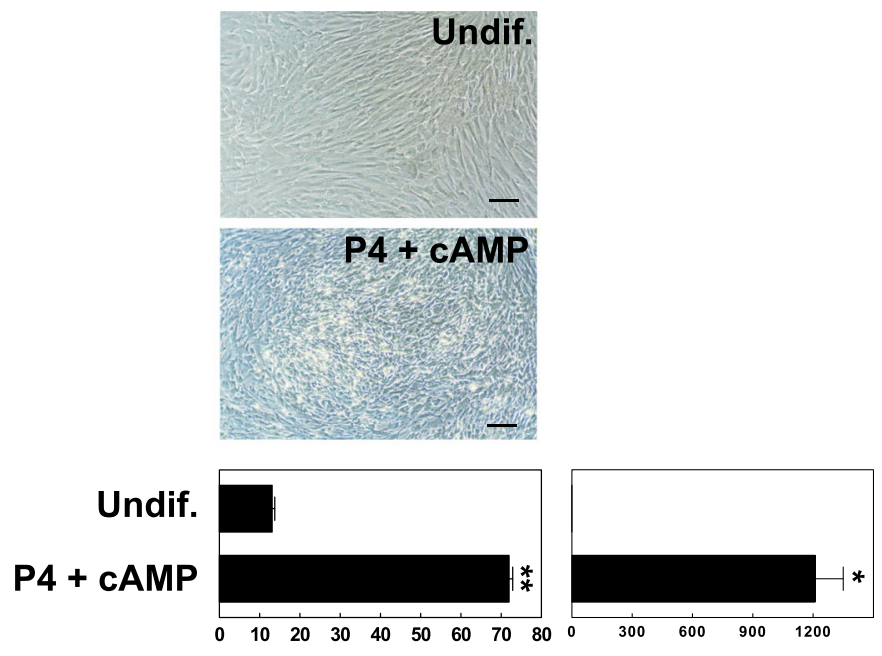

Round cells (\%) Prolactin (ng/106 cells)

B

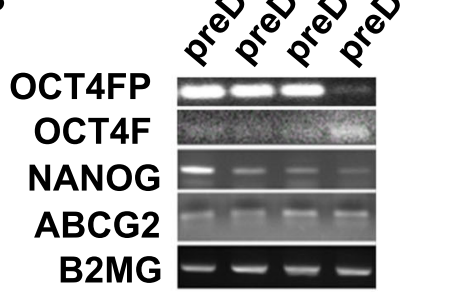

D

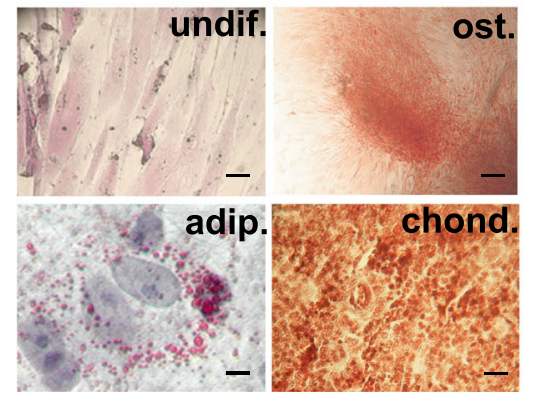

C

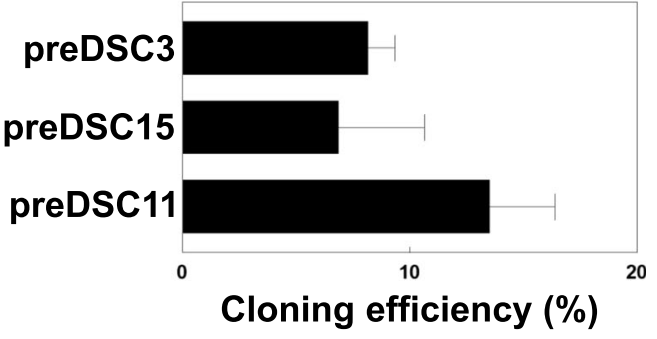

Fig. 1 Characteristics of preDSC lines. a Decidualization. After 14 days of culture with P4 and cAMP, undifferentiated preDSCs (Undif.) changed from a fibroblastic to a rounder shape (left) and secreted PRL (right). The bars show the percentage of round cells and the secretion of PRL by a preDSC line (mean \pm SD of three independent determinations). Scale bar, $50 \mu \mathrm{m}$. b Detection by RT-PCR of pluripotent stem cell markers in four preDSC lines. c Cloning efficiencies of the three preDSC lines. d Mesenchymal differentiation of a preDSC line. Undifferentiated preDSCs (undif.), osteogenic (ost.), adipogenic (adip.), and chondrogenic (chond.) differentiated preDSCs. Differentiation was documented with alizarin staining (ost.), oil red O solution (adip.), and safranin O (chond.). Scale bar, $50 \mu \mathrm{m}$. Molecular markers of differentiation were detected by RT-PCR: PPARy2 (adip.), collagen type II (chond.), osteopontin, and AP (ost.). AP and osteopontin were also positive in undifferentiated preDSC lines [25, 28]. Beta-2 microglobulin (B2MG) was used as the loading control. The bars represent mean \pm SD of three independent determinations. These experiments were done in 4 independent replications. ${ }^{*} P<0.001,{ }^{* *} P<0.0005$

morphology changed from a fibroblastic to a rounder shape, and they began to secrete PRL (Fig. 1a) [8-13]. Furthermore, the antigen phenotype of these preDSC lines was previously studied and found to be fully compatible with that of bone marrow MSCs $[5,19]$ (Table 1). This antigen phenotype, together with the adherence of preDSCs to plastic culture dishes and their capacity to differentiate into adipocytes, osteoblasts, and 


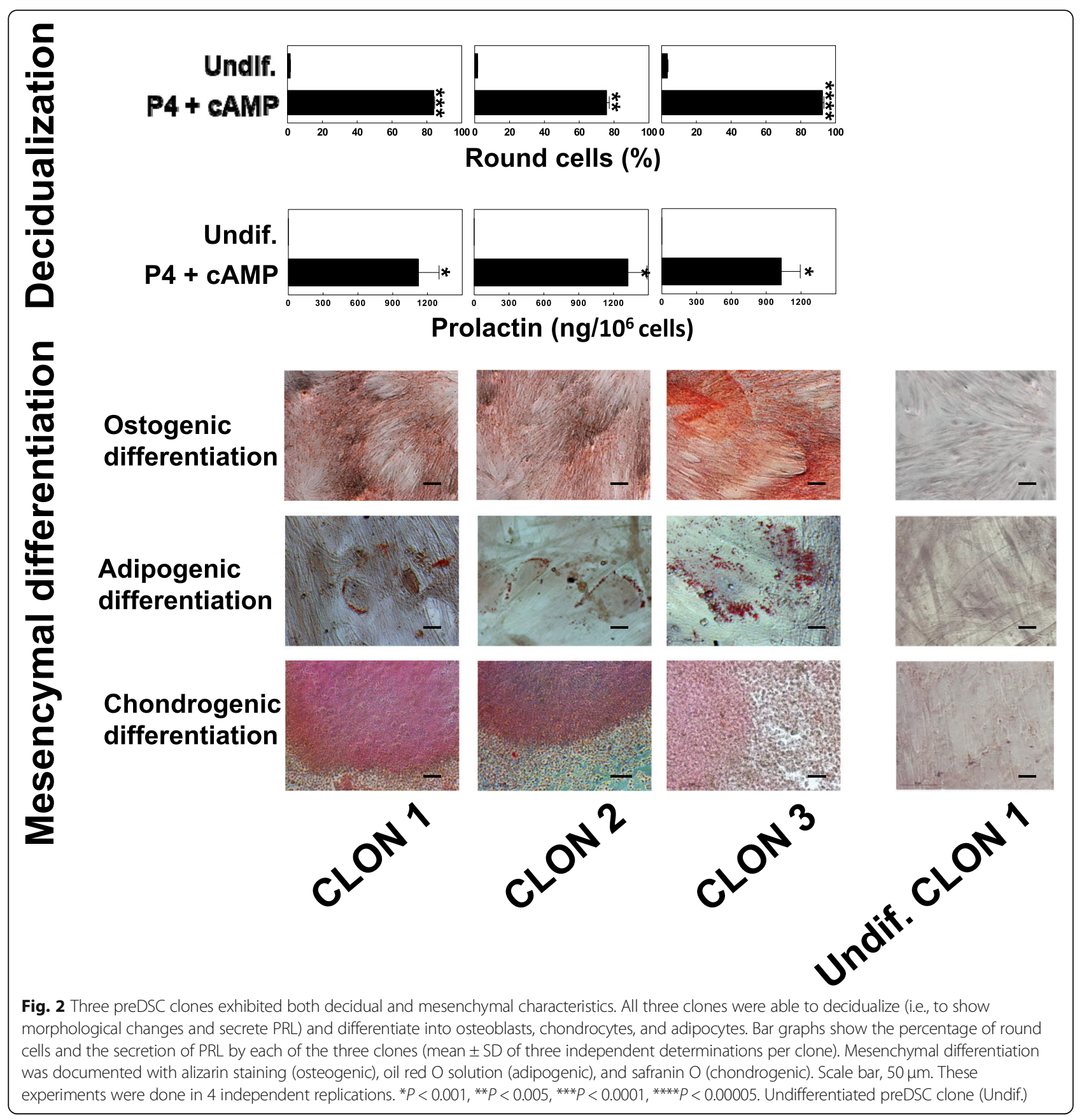

chondrocytes (Fig. 1d), are properties that, taken together, meet the minimal criteria proposed by the International Society for Cellular Therapy (ISCT) to define human MSCs [37]. The possibility that these MSC and DSC properties were due to the presence of different cell subpopulations in our preDSC lines was ruled out. The facts that all three of the preDSC clones we obtained exhibited an antigen phenotype like that of preDSC lines [19], and therefore equivalent to that of MSCs, and underwent mesenchymal and decidual differentiation (Fig. 2) demonstrate that single type of cell, i.e., preDSCs, exhibited both DSC and MSC characteristics. Other MSC features are the expression of stem cell markers, clonogenicity, and immunoregulatory activities [32]. Likewise, preDSC lines expressed the multipotentiality markers OCT-4, NANOG, and ABCG2, their clonogenic efficiency ranged between 4 and $15 \%$ (Fig. 1), they remained alive for weeks in xenogeneic transplants (Fig. 4), and they had a therapeutic effect in an immune-based murine model of spontaneous abortion (Fig. 3). Taken together, these findings confirm the close relationship between bone marrow MSCs and preDSCs (Table 4). 


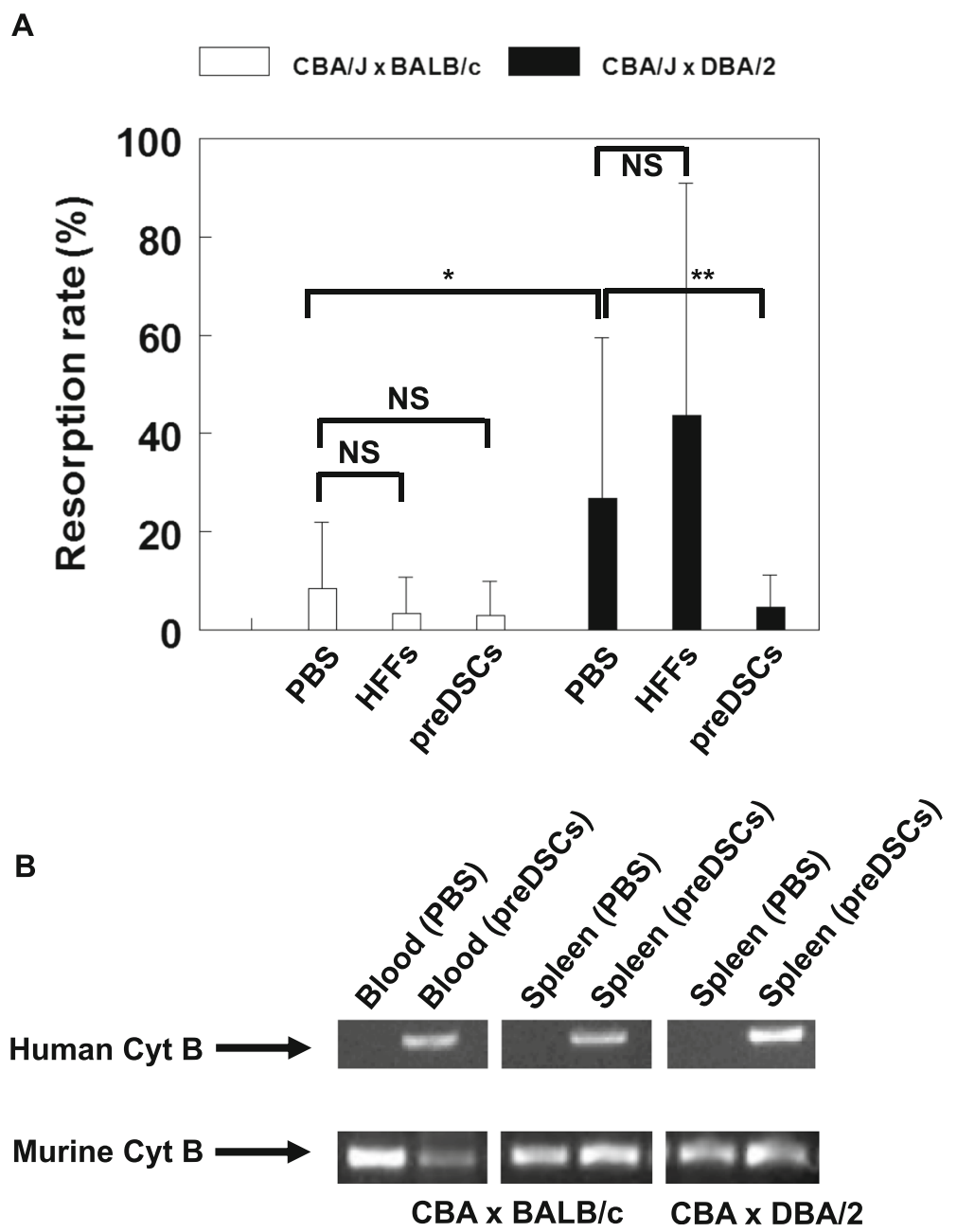

Fig. 3 PreDSCs inhibited the resorption rate in the abortion-prone CBA/Jq $\times D B A / 20$ combination. preDSCs, HFFs, or PBS were injected on day 2 of gestation in CBA/J mice mated to DBA/2 mice or control BALB/c mice, and the rate of embryo resorption (percentage of reabsorbed embryos referred to the total number of embryo implantations) was determined on day 14 of gestation. a The resorption rate (mean \pm SD) was

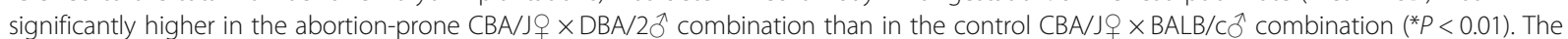
injection of preDSCs significantly decreased the abortion rate in $C B A / J q \times D B A / 2 \hat{\sigma}$ matings $(* * P<0.001)$. The injection of HFFs increased the abortion rate, but not significantly. b PreDSCs were detected by human Cyt B PCR in the blood and spleen of BALB/C-mated pregnant CBA/J mice and in the spleen of DBA/2-mated pregnant CBA/J mice in which preDSCs were injected. None of the control mice, in which preDSCs were not injected (PBS), was positive. Murine Cyt B PCR was positive in all samples

Dimitrov et al., also using human preDSC lines, found an association between these cells and MSCs [31]. This connection suggests that MSCs home to the nongestational endometrium or the decidua to develop into preDSCs. This possibility is supported by the finding of endometrial cells of donor origin in the uterus of women who received bone marrow transplants [50].

A single-cell transcriptomics approach was used by Vento-Tormo et al., who identified different cell types in the first-trimester human placenta. The cellular composition of

Table 3 Detection of preDSCs in tissues of immunocompetent mice in which human preDSCs were injected

\begin{tabular}{lllll}
\hline Strain & Cells injected/method of detection & Blood & Lymph nodes & Spleen \\
\hline CBA/J & PreDSCs/RT-PCR & Day 12: 3/3 & ND & Day 12: 2/6 \\
BALB/C & PreDSC-GFP/Flow cytometry & Day 2: 3/3 & Day 2: 0/3 & Day 2: 0/3 \\
& & Day 45: 0/3 & Day 45: 1/3 & Day 30: 1/3 \\
\hline
\end{tabular}

${ }^{b} 3$ positive mice out of 3

c1/3 DBA/2-mated pregnant $\mathrm{CBA} / \mathrm{J}$ and $1 / 3$ in BALB/c-mated pregnant CBA/J 


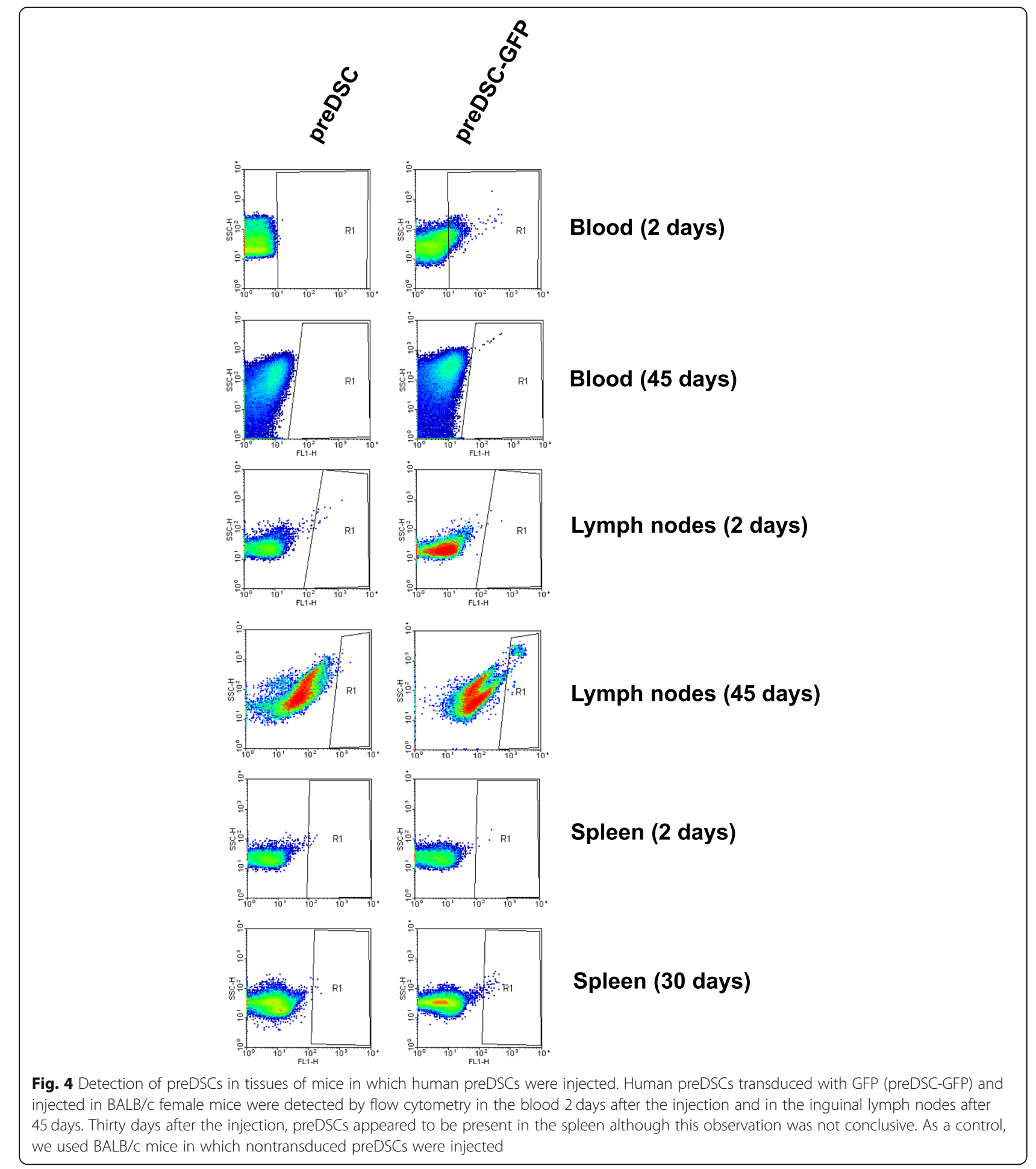

human decidua includes the presence of perivascular cells, with an antigen phenotype (CD146+ CD140b+, W5C5+, $\alpha$-SM actin+, CD29+, ANGPT1+, and VCGFA+) consistent with that reported by us for preDSCs, cells that also exhibit a perivascular location (Table 1) $[19,51]$. We demonstrated the close relationship between human
preDSCs and pericytes [19], the latter also being a perivascular cell type closely associated with-possibly even identical to-MSCs [22-24]. PreDSCs also appear to correspond to the MSCs in the human endometrium reported by other authors (endometrial MSCs, eMSCs), i.e., clonogenic, self-renewing, multipotent cells that can differentiate 
Table 4 Comparison of preDSCs and MSCs

\begin{tabular}{|c|c|c|c|}
\hline Characteristics & PreDSCs & MSCs & References \\
\hline Antigen phenotype & Table 1 & Table 1 & {$[5,19,36]$} \\
\hline ISCT minimal criteria & + & + & {$[19,37]$} \\
\hline Decidualization & PRL (mRNA+, protein+) & PRL (mRNA+, protein-) & [5] \\
\hline Mesenchymal differentiation & + & + & This work, [37] \\
\hline Cell contractility & + & + & {$[19,29]$} \\
\hline Stem cell markers & + & + & This work, [43] \\
\hline Clonogenicity & + & + & This work, [45] \\
\hline Apoptosis resistance & + & + & {$[27,30]$} \\
\hline Hematopoietic cell supportive activity & + & + & {$[18,46]$} \\
\hline Survival in xenotransplants & + & + & This work, $[47,48]$ \\
\hline Perivascular location & + & + & {$[19,49]$} \\
\hline In vivo and in vitro immunoregulatory activity & + & + & This work $[5,7,23]$ \\
\hline
\end{tabular}

into adipogenic, osteogenic, chondrogenic, and myogenic lineages [52]. Like preDSCs, eMSCs are CD146+, $\mathrm{CD} 140 \mathrm{~b}+$, and $\mathrm{W} 5 \mathrm{C} 5+$, decidualize, are found in perivascular sites, and have also been associated with pericytes [19, 53-56]. However, eMSCs were isolated by cell sorting from nongestational endometrium samples, whereas the preDSC lines we obtained from the decidua were enriched by cell culture [19].

Bone marrow or fat MSCs exert immunoregulatory activities that support therapeutic effects against inflammatory and autoimmune diseases [32]. In the present study, we show that preDSCs survived in xenogeneic transplants in vivo for prolonged periods in immunocompetent mice (Fig. 4). This result is consistent with the findings that demonstrated the long-term survival of human MSCs in immunocompetent mice [47] and rats [48]. Although the immunological mechanisms involved in our in vivo experiments were not studied, several lines of experimental evidence confirm that MSCs function across species barriers [57]. In this connection, it has been shown before that human DSCs can interact with the rat and mouse immune systems $[58,59]$. The expression of HLA-G and the secretion of IL-10 by preDSCs [3] may be additional mechanisms involved in the induction of tolerance and escape from the immune response in xenotransplants $[60,61]$. Other immunoregulatory properties, such as the induction of $\mathrm{T}$ regulatory cells (Tregs), detected in MSCs and DSCs [62, 63], and our own unpublished data, may explain the escape from immune rejection in allo- and xenotransplants. In this connection, it was proposed that MSCs play a key role in the physiological mechanisms of immune self-tolerance [23]. Likewise, preDSCs play a role in local mechanisms of maternal-fetal immune tolerance that support normal pregnancy $[3,18]$. The abortion-prone mating of female CBA/J mice with male DBA/2 mice is an animal model of human immunologically mediated spontaneous abortion in which the maternal-fetal immune tolerance has broken down [33, 34]. We considered this murine model appropriate to investigate both the potential regulatory effect of preDSCs in immune-based human recurrent abortion and the role of preDSCs in maintaining maternal-fetal immune tolerance. This hypothetical function of preDSCs is supported by our finding that the injection of preDSCs in $\mathrm{CBA} / \mathrm{J}$ females mated to DBA males significantly decreased the embryo resorption rate (Fig. 3, Additional file 1: Table S1). Similarly, syngeneic murine fat MSCs were shown to be therapeutically effective in this model [64]. Other reports have also documented the beneficial effects of human DSCs in steroid-refractory graft-versus-host disease in humans $[65,66]$, a finding that identifies DSCs as a potentially important component of cell therapies for immune-mediated diseases. In this connection, the availability of purified, expandable preDSC lines may help to facilitate further research on the clinical applications in the treatment of inflammatory and autoimmune diseases.

\section{Conclusions}

Our data show that preDSCs are decidual MSCs that exhibit immunoregulatory activities that may be relevant in the decidual mechanisms of maternal-fetal immune tolerance. These cells may also be beneficial in the treatment of immune-mediated diseases.

\section{Additional file}

Additional file 1: Table S1. Effect of preDSCs on the embryo resorption rate in the abortion-prone $\mathrm{CBA} / \mathrm{J} \times \mathrm{DBA} / 2$ combination and control CBA/J × BALB/c combination. (DOC $30 \mathrm{~kb}$ )

\section{Abbreviations}

ABCG2: ATP-binding cassette subfamily G member 2; AP: Alkaline phosphatase; B2MG: Beta-2 microglobulin; CE: Cloning efficiency; CMV: Cytomegalovirus; Cyt B: Cytochrome B; DSC: Decidual stromal cells; FCS: Fetal calf serum; GFP: Green fluorescent protein; HFFs: Human foreskin 
fibroblasts; MSC: Mesenchymal stromal/stem cells; OCT-4: Octamer-binding transcription factor 4; P4: Progesterone; PPARY2: Peroxisome proliferatoractivated receptor Y2; PreDSCs: Precursors of DSC; PRL: Prolactin; RT$P C R$ : Reverse transcription polymerase chain reaction; VSVg: Vesicular stomatitis virus $\mathrm{G}$ glycoprotein; $\mathrm{a}-\mathrm{SM}$ actin: $\mathrm{a}$-Smooth muscle actin

\section{Acknowledgements}

This article contributes to the COST Action CA17116 "International Network for Translating Research on Perinatal Derivatives into Therapeutic Approaches (SPRINT)", supported by COST (European Cooperation in Science and Technology). We are grateful to Dr. S. Jordán from the Clínica el Sur (Málaga, Spain) and Dr. F. García Gallego from the Clínica Ginegranada (Granada, Spain) for providing the decidual specimens. We thank K. Shashok for improving the use of English in the manuscript.

\section{Authors' contributions}

RMF contributed to the conception and design, administrative support, and collection and/or assembly of the data and data analysis and interpretation. CM contributed to the administrative support, collection and/or assembly of the data, and data analysis and interpretation. FR contributed to the data analysis and interpretation. FM was responsible for the provision of the study material or patients and data analysis and interpretation. PFR, TL, and MJRM contributed to the collection and/or assembly of the data and data analysis and interpretation. CRR and EGO were responsible for the conception and design, financial support, provision of the study material or patients, collection and/or assembly of data, data analysis and interpretation, and manuscript writing. All authors read and approved the final manuscript.

\section{Funding}

This work was supported by the Plan Estatal de Investigación Científica y Técnica y de Innovación 2013-2016, ISCIII-Subdirección General de Evaluación y Fomento de la Investigación, the Ministerio de Economía y Competitividad, Spain (Grant PI16/01642) and European Regional Development Fund (ERDF/ FEDER funding), the European Community, and the Cátedra de Investigación Anto nio Chamorro-Alejandro Otero, Universidad de Granada (CACH2017-1).

\section{Availability of data and materials}

All data generated or analyzed during this study are included in this published article.

\section{Ethics approval and consent to participate}

Informed consent was obtained from each sample donor. All experimental procedures were carried out according to the Real Decreto 53/2013 (BOE, 34, 11370-11421, 2013) regarding animal research ethics. In accordance with the regulations of the University of Granada on the use of animals, all the authors consider that animals are creatures of great complexity and intrinsic value, and worthy of respect, so their use can only aim to advance scientific knowledge and improve the health of humans or animals. During the present work, attempts were made to replace in vivo experiments with in vitro experiments whenever possible, using the minimum number of animals that would allow statistically meaningful results to be obtained and scientific conclusions to be drawn with confidence. This study was approved by the Research and Ethics Committee of the University of Granada.

\section{Consent for publication}

Not applicable

\section{Competing interests}

The authors declare that they have no competing interests.

\section{Author details}

${ }^{1}$ Instituto de Biopatología y Medicina Regenerativa, Centro de Investigación Biomédica, Universidad de Granada, Granada, Spain. ²Departamento de Estadística e Investigación Operativa, Universidad de Granada, Granada, Spain. ${ }^{3}$ Human DNA Variability Department, GENYO - Centre for Genomic and Oncological Research (Pfizer/University of Granada/Andalusian Regional Government), PTS Granada, Granada, Spain. ${ }^{4}$ Departamento de Bioquímica y Biología Molecular III e Inmunología, Facultad de Medicina, Universidad de Granada, Avenida de la Investigación, 11, 18016 Granada, Spain. ${ }^{5}$ Unidad de Gestión Clínica Laboratorios, Hospital Universitario San Cecilio, Granada, Spain.
Received: 23 April 2019 Revised: 28 May 2019

Accepted: 29 May 2019 Published online: 14 June 2019

\section{References}

1. Macklon NS, Brosens JJ. The human endometrium as a sensor of embryo quality. Biol Reprod. 2014;91(4):98.

2. Sharma S, Godbole G, Modi D. Decidual control of trophoblast invasion. Am J Reprod Immunol. 2016;75(3):341-50.

3. Blanco O, Tirado I, Munoz-Fernandez R, Abadia-Molina AC, Garcia-Pacheco JM, Pena J, et al. Human decidual stromal cells express HLA-G: effects of cytokines and decidualization. Hum Reprod. 2008;23(1):144-52.

4. Kimatrai M, Blanco O, Munoz-Fernandez R, Tirado I, Martin F, Abadia-Molina AC, et al. Contractile activity of human decidual stromal cells. II. Effect of interleukin-10. J Clin Endocrinol Metab. 2005;90(11):6126-30.

5. Munoz-Fernandez R, Prados A, Leno-Duran E, Blazquez A, Garcia-Fernandez $J R$, Ortiz-Ferron G, et al. Human decidual stromal cells secrete C-X-C motif chemokine 13 , express B cell-activating factor and rescue B lymphocytes from apoptosis: distinctive characteristics of follicular dendritic cells. Hum Reprod. 2012;27(9):2775-84.

6. Nancy P, Tagliani E, Tay CS, Asp P, Levy DE, Erlebacher A. Chemokine gene silencing in decidual stromal cells limits T cell access to the maternal-fetal interface. Science. 2012;336(6086):1317-21.

7. Vacca P, Montaldo E, Vitale C, Croxatto D, Moretta L, Mingari MC. MSC and innate immune cell interactions: a lesson from human decidua. Immunol Lett. 2015;168(2):170-4.

8. Ferenczy A, Guralnick M. Endometrial microstructure: structure-function relationships throughout the menstrual cycle. Semin Reprod Endocrinol. 1983;1(03):205-19.

9. Wynn RM. Ultrastructural development of the human decidua. Am J Obstet Gynecol. 1974;118(5):652-70.

10. Bergeron C. Morphological changes and protein secretion induced by progesterone in the endometrium during the luteal phase in preparation for nidation. Hum Reprod. 2000;15(Suppl 1):119-28.

11. Braverman MB, Bagni A, de Ziegler D, Den T, Gurpide E. Isolation of prolactin-producing cells from first and second trimester decidua. J Clin Endocrinol Metab. 1984;58(3):521-5.

12. Frame LT, Wiley L, Rogol AD. Indirect immunofluorescent localization of prolactin to the cytoplasm of decidua and trophoblast cells in human placental membranes at term. J Clin Endocrinol Metab. 1979;49(3):435-7.

13. Olivares EG, Montes MJ, Oliver C, Galindo JA, Ruiz C. Cultured human decidual stromal cells express B7-1 (CD80) and B7-2 (CD86) and stimulate allogeneic T cells. Biol Reprod. 1997;57(3):609-15.

14. Kyurkchiev S, Shterev A, Dimitrov R. Assessment of presence and characteristics of multipotent stromal cells in human endometrium and decidua. Reprod BioMed Online. 2010;20(3):305-13.

15. Miehe U, Neumaier-Wagner P, Kadyrov M, Goyal P, Alfer J, Rath W, et al. Concerted upregulation of CLP36 and smooth muscle actin protein expression in human endometrium during decidualization. Cells Tissues Organs. 2005;179(3):109-14.

16. Polyzos PT, Arvanitis LD, Charchanti A, Galani V, Havaki S, Kallioras VA, et al. Decidualized and pre-decidualized normal endometrial stromal cells produce more O-linked $\mathrm{N}$-acetylglucosamine containing epitope $\mathrm{H}$ than non-decidualized normal endometrial stromal cells. Histol Histopathol. 2006; 21(11):1193-8.

17. Huang JR, Tseng $L$, Bischof $P$, Janne OA. Regulation of prolactin production by progestin, estrogen, and relaxin in human endometrial stromal cells. Endocrinology. 1987;121(6):2011-7.

18. Blanco O, Leno-Duran E, Morales JC, Olivares EG, Ruiz-Ruiz C. Human decidual stromal cells protect lymphocytes from apoptosis. Placenta. 2009; 30(8):677-85.

19. Munoz-Fernandez R, de la Mata C, Prados A, Perea A, Ruiz-Magana MJ, Llorca $T$, et al. Human predecidual stromal cells have distinctive characteristics of pericytes: cell contractility, chemotactic activity, and expression of pericyte markers and angiogenic factors. Placenta. 2018; 61:39-47.

20. Armulik A, Genove G, Betsholtz C. Pericytes: developmental, physiological, and pathological perspectives, problems, and promises. Dev Cell. 2011;21(2): 193-215.

21. Diaz-Flores L, Gutierrez R, Madrid JF, Varela H, Valladares F, Acosta E, et al. Pericytes. Morphofunction, interactions and pathology in a quiescent and activated mesenchymal cell niche. Histol Histopathol. 2009;24(7):909-69. 
22. Caplan Al, Correa D. The MSC: an injury drugstore. Cell Stem Cell. 2011; 9(1):11-5.

23. da Silva Meirelles L, Caplan Al, Nardi NB. In search of the in vivo identity of mesenchymal stem cells. Stem Cells. 2008;26(9):2287-99.

24. da Silva Meirelles L, Malta TM, Panepucci RA, da Silva WA Jr. Transcriptomic comparisons between cultured human adipose tissue-derived pericytes and mesenchymal stromal cells. Genom Data. 2016;7:20-5.

25. Garcia-Pacheco JM, Oliver C, Kimatrai M, Blanco FJ, Olivares EG. Human decidual stromal cells express CD34 and STRO-1 and are related to bone marrow stromal precursors. Mol Hum Reprod. 2001;7(12):1151-7.

26. Block GJ, Ohkouchi S, Fung F, Frenkel J, Gregory C, Pochampally R, et al. Multipotent stromal cells are activated to reduce apoptosis in part by upregulation and secretion of stanniocalcin-1. Stem Cells. 2009;27(3): 670-81.

27. Dimitriou H, Perdikogianni C, Martimianaki G, Choumerianou DM, Pelagiadis J, Kalmanti M. Are mesenchymal stromal cells from children resistant to apoptosis? Cell Prolif. 2009:42(3):276-83.

28. Kimatrai M, Oliver C, Abadia-Molina AC, Garcia-Pacheco JM, Olivares EG. Contractile activity of human decidual stromal cells. J Clin Endocrinol Metab. 2003;88(2):844-9.

29. Kinner B, Zaleskas JM, Spector M. Regulation of smooth muscle actin expression and contraction in adult human mesenchymal stem cells. Exp Cell Res. 2002;278(1):72-83.

30. Leno-Duran E, Ruiz-Magana MJ, Munoz-Fernandez R, Requena F, Olivares EG, Ruiz-Ruiz C. Human decidual stromal cells secrete soluble pro-apoptotic factors during decidualization in a CAMP-dependent manner. Hum Reprod. 2014;29(10):2269-77.

31. Dimitrov R, Kyurkchiev D, Timeva T, Yunakova M, Stamenova M, Shterev A, et al. First-trimester human decidua contains a population of mesenchymal stem cells. Fertil Steril. 2010;93(1):210-9.

32. Uccelli A, Moretta L, Pistoia V. Mesenchymal stem cells in health and disease. Nat Rev Immunol. 2008:8(9):726-36.

33. Bonney EA, Brown SA. To drive or be driven: the path of a mouse model of recurrent pregnancy loss. Reproduction. 2014;147(5):R153-67.

34. Jin LP, Li DJ, Zhang JP, Wang MY, Zhu XY, Zhu Y, et al. Adoptive transfer of paternal antigen-hyporesponsive $T$ cells induces maternal tolerance to the allogeneic fetus in abortion-prone matings. J Immunol. 2004;173(6):3612-9.

35. Sumathi VP, McCluggage WG. CD10 is useful in demonstrating endometrial stroma at ectopic sites and in confirming a diagnosis of endometriosis. J Clin Pathol. 2002:55(5):391-2.

36. Prados A, Munoz-Fernandez R, Fernandez-Rubio P, Olivares EG. Characterization of mesenchymal stem/stromal cells with lymphoid tissue organizer cell potential in tonsils from children. Eur J Immunol. 2018;48(5):829-43.

37. Dominici M, Le Blanc K, Mueller I, Slaper-Cortenbach I, Marini F, Krause D, et al. Minimal criteria for defining multipotent mesenchymal stromal cells. The International Society for Cellular Therapy position statement. Cytotherapy. 2006:8(4):315-7.

38. Liedtke S, Enczmann J, Waclawczyk S, Wernet P, Kogler G. Oct4 and its pseudogenes confuse stem cell research. Cell Stem Cell. 2007;1 (4):364-6.

39. Benabdellah K, Cobo M, Munoz P, Toscano MG, Martin F. Development of an all-in-one lentiviral vector system based on the original TetR for the easy generation of Tet-ON cell lines. PLoS One. 2011;6(8):e23734

40. Toscano MG, Frecha C, Benabdellah K, Cobo M, Blundell M, Thrasher AJ, et al. Hematopoietic-specific lentiviral vectors circumvent cellular toxicity due to ectopic expression of Wiskott-Aldrich syndrome protein. Hum Gene Ther. 2008;19(2):179-97.

41. Munoz P, Toscano MG, Real PJ, Benabdellah K, Cobo M, Bueno C, et al. Specific marking of hESCs-derived hematopoietic lineage by WAS-promoter driven lentiviral vectors. PLoS One. 2012;7(6):e39091.

42. Rao JNK, Scott AJ. The analysis of categorical-data from complex samplesurveys - chi-squared tests for goodness of fit and independence in 2-way tables. J Am Stat Assoc. 1981;76(374):221-30.

43. Guillot PV, Gotherstrom C, Chan J, Kurata H, Fisk NM. Human first-trimester fetal MSC express pluripotency markers and grow faster and have longer telomeres than adult MSC. Stem Cells. 2007;25(3):646-54.

44. Halter $\mathrm{M}$, Tona A, Bhadriraju K, Plant AL, Elliott JT. Automated live cell imaging of green fluorescent protein degradation in individual fibroblasts. Cytometry A. 2007;71(10):827-34.

45. Colter DC, Class R, DiGirolamo CM, Prockop DJ. Rapid expansion of recycling stem cells in cultures of plastic-adherent cells from human bone marrow. Proc Natl Acad Sci U S A. 2000;97(7):3213-8.
46. Mendez-Ferrer S, Michurina TV, Ferraro F, Mazloom AR, Macarthur BD, Lira $S A$, et al. Mesenchymal and haematopoietic stem cells form a unique bone marrow niche. Nature. 2010;466(7308):829-34.

47. Niemeyer P, Vohrer J, Schmal H, Kasten P, Fellenberg J, Suedkamp NP, et al. Survival of human mesenchymal stromal cells from bone marrow and adipose tissue after xenogenic transplantation in immunocompetent mice. Cytotherapy. 2008;10(8):784-95.

48. Paul A, Srivastava S, Chen G, Shum-Tim D, Prakash S. Functional assessment of adipose stem cells for xenotransplantation using myocardial infarction immunocompetent models: comparison with bone marrow stem cells. Cell Biochem Biophys. 2013;67(2):263-73.

49. Crisan M, Yap S, Casteilla L, Chen CW, Corselli M, Park TS, et al. A perivascular origin for mesenchymal stem cells in multiple human organs. Cell Stem Cell. 2008;3(3):301-13.

50. Taylor HS. Endometrial cells derived from donor stem cells in bone marrow transplant recipients. JAMA. 2004;292(1):81-5.

51. Vento-Tormo R, Efremova M, Botting RA, Turco MY, Vento-Tormo M, Meyer $\mathrm{KB}$, et al. Single-cell reconstruction of the early maternal-fetal interface in humans. Nature. 2018:563(7731):347-53.

52. Gargett $C E$, Schwab KE, Deane JA. Endometrial stem/progenitor cells: the first 10 years. Hum Reprod Update. 2016;22(2):137-63.

53. Aghajanova L, Horcajadas JA, Esteban FJ, Giudice LC. The bone marrowderived human mesenchymal stem cell: potential progenitor of the endometrial stromal fibroblast. Biol Reprod. 2010;82(6):1076-87.

54. Masuda H, Anwar SS, Buhring HJ, Rao JR, Gargett CE. A novel marker of human endometrial mesenchymal stem-like cells. Cell Transplant. 2012; 21(10):2201-14.

55. Schwab KE, Gargett CE. Co-expression of two perivascular cell markers isolates mesenchymal stem-like cells from human endometrium. Hum Reprod. 2007;22(11):2903-11.

56. Spitzer TL, Rojas A, Zelenko Z, Aghajanova L, Erikson DW, Barragan F, et al. Perivascular human endometrial mesenchymal stem cells express pathways relevant to self-renewal, lineage specification, and functional phenotype. Biol Reprod. 2012;86(2):58.

57. Li J, Ezzelarab MB, Cooper DK. Do mesenchymal stem cells function across species barriers? Relevance for xenotransplantation. Xenotransplantation. 2012;19(5):273-85.

58. Chen CP, Liu SH, Huang JP, Aplin JD, Wu YH, Chen PC, et al. Engraftment potential of human placenta-derived mesenchymal stem cells after in utero transplantation in rats. Hum Reprod. 2009;24(1):154-65.

59. Sadeghi B, Heshmati $Y$, Khoein B, Kaipe H, Uzunel M, Walfridsson J, et al. Xeno-immunosuppressive properties of human decidual stromal cells in mouse models of alloreactivity in vitro and in vivo. Cytotherapy. 2015:17(12):1732-45.

60. Ding DC, Chou HL, Chang YH, Hung WT, Liu HW, Chu TY. Characterization of HLA-G and related immunosuppressive effects in human umbilical cord stroma-derived stem cells. Cell Transplant. 2016;25(2):217-28.

61. Rouas-Freiss N, LeMaoult J, Moreau P, Dausset J, Carosella ED. HLA-G in transplantation: a relevant molecule for inhibition of graft rejection? Am J Transplant. 2003:3(1):11-6.

62. Erkers T, Nava S, Yosef J, Ringden O, Kaipe H. Decidual stromal cells promote regulatory $T$ cells and suppress alloreactivity in a cell contactdependent manner. Stem Cells Dev. 2013;22(19):2596-605.

63. Maccario R, Podesta M, Moretta A, Cometa A, Comoli P, Montagna D, et al. Interaction of human mesenchymal stem cells with cells involved in alloantigen-specific immune response favors the differentiation of CD4+ Tcell subsets expressing a regulatory/suppressive phenotype. Haematologica. 2005;90(4):516-25

64. Sadighi-Moghaddam B, Salek Farrokhi A, Namdar Ahmadabad H, Barati M, Moazzeni SM. Mesenchymal stem cell therapy prevents abortion in CBA/J $x$ DBA/2 mating. Reprod Sci. 2018:25(8):1261-9.

65. Ringden O, Baygan A, Remberger M, Gustafsson B, Winiarski J, Khoein B, et al. Placenta-derived decidua stromal cells for treatment of severe acute graft-versus-host disease. Stem Cells Transl Med. 2018;7(4):325-31.

66. Ringden O, Erkers T, Nava S, Uzunel M, Iwarsson E, Conrad R, et al. Fetal membrane cells for treatment of steroid-refractory acute graft-versus-host disease. Stem Cells. 2013;31(3):592-601. 